\title{
Metaphors in Political Discourse in Kenya: Unifying or Divisive?
}

\author{
Raphael Francis Otieno (Corresponding author) \\ Department of Languages Linguistics and Literature, \\ Jaramogi Oginga Odinga University of Science and Technology, Kenya
}

$\begin{array}{lr}\text { Received: February 14, } 2019 & \text { Accepted: May 14, } 2019 \quad \text { Published: June 12, } 2019 \\ \text { doi:10.5296/ijld.v9i2.14918 } & \text { URL: https://doi.org/10.5296/ijld.v9i2.14918 }\end{array}$

\begin{abstract}
Metaphor has been viewed as a tool that is used in political discourse to structure human thought. In the structuring function of metaphor, it is assumed that there is a similarity between the source and the target domains. However, the similar structure in the target domain does not always exist before the metaphor is coined (Lakoff \& Turner, 1989). Rather, the metaphor can create the similar structure in the target domain. The politicians' reference to war, religion, business and animals among others, therefore, serves to structure and limit the thought of the electorates to view politics from certain perspectives. The basic argument in this study is, therefore, that metaphors are ingrained in our conceptual faculties and play a significant role in structuring our thought patterns in politics. The structuring through metaphor can, however, either be positive and/or negative. In other words, the structuring could either be unifying or divisive. As Rozina (2001:12) asserts, '...political discourse is primarily focused on persuading people to take specified political actions or to make crucial political decisions.' Using the Conceptual Metaphor Theory (CMT) and Critical Metaphor Analysis (CMA), this study investigated the extent to which metaphors in political discourse in Kenya create, reflect or symbolize the values of national unity and inclusiveness enshrined in the Constitution of Kenya. The study found that both positive and negative axiological values are present in metaphors in political discourse in Kenya. However, the negative axiological value overrides the positive value.
\end{abstract}

Keywords: Metaphor, unifying, divisive, political discourse, conceptual metaphor theory, critical metaphor analysis

\section{Introduction}

Since the re-introduction of competitive politics in Kenya following the repeal of section 2(a) of the Constitution that had made Kenya a de facto single party state, several political parties 
compete for political power. General Elections in Kenya, held every five (5) years, are preceded by campaigns by various political parties and their candidates. The campaigns provide a platform for political candidates to market and popularize themselves as well as their parties. During these campaigns, more often than not, it is not only what the politicians say that delivers the message; rather it is how they say it. Roberts (1954: 182) notes that 'it is not enough to know what to say, one must also know how to say it.' Metaphor is one of the strategies used in political communication the world over. This study, therefore, assessed the extent to which metaphors in political discourse in Kenya create, reflect or symbolize the values of national unity and inclusiveness enshrined in Section 10, Sub-Section 2(a) and (b) of the Constitution of Kenya.

\subsection{National Values and Principles of Governance in the Kenyan Constitution}

Personal values are a set of personal principles, standards, concepts, beliefs and ideas that can be used to make everyday decisions. They develop from circumstances surrounding us and can change over time. Value concepts are universal but personal values are not because each individual possesses a unique view of the concepts. Cultural values, on the other hand, are values that are shared by members of groups, societies or cultures. Brand Kenya, a state corporation with the mandate of ensuring that an integrated national brand is created, defines values as practices, culture and traits that define a people. They are viewed as enduring beliefs or ideals shared by members of a culture about what is good or desirable and what is not. Values exert a major influence on the behavior of an individual and serve as broad guidelines in all situations. Our values assist us in the articulation of who we are, what we stand for and how we would like the world to view us (Brand Kenya).Flying the national flag of Kenya on a national holiday is a norm which reflects the values of patriotism.

To enhance and promote nationalism and social cohesion in Kenya, each Kenyan ought to be committed to a set of values. Kenya's national values, which are binding, are derived from the Kenyan Constitution that was promulgated in 2010. The National values and Principles of Good Governance in Section 10, Sub-Section 2(a) and (b) state that the national values and principles of good governance include:

(a) Patriotism, national unity, sharing and devolution of power, the rule of law, democracy and participation of the people;

(b) Human dignity, equity, social justice, inclusiveness, equality, human rights, non-discrimination and protection of the marginalized.

It is in this respect that the study set out to assess the extent to which metaphors in political discourse in Kenya create, reflect or symbolize Kenya's values of national unity and inclusiveness.

\section{Literature Review}

Studies conducted on the axiological value of metaphors have established that metaphors can either create positive images for the politician, or assign absurd images to one's opponent (Wilson, 1990).Van Dijk (1997) supports this idea when he states that politicians often use 
metaphorical association to elicit positive self and negative other-presentation. Image schemas are capable of endowing an expression with a strong axiological value, either positive or negative (Isabel \& Velasco, 2001).

Opeibi (2006), while studying negative political advertising, observed that many of the political office aspirants abandoned positive, issue-focused advertisement and engaged in rhetorical strategies of direct attacks on their opponents. Mensah (2012) opines that positive or negative associations of source domain over a period of time can become a natural part of it.

Metaphors from the magazines Time and Newsweek from around the period of the 1991 Gulf War were studied by Sandikcioglu (2000) who argued that the metaphors demonstrated a racist agenda, in which the world is polarized into 'the Orient vs. the West, US vs. Them.' Santa Ana (1999) analyzed metaphors in articles from the Los Angeles Times reporting on anti-immigrant legislation, and found that they constructed immigrants negatively as animals, plants and commodities. The nation was metaphorically constructed as a house, and immigrants talked of as metaphorical threats such as floods or invasion. The 'us' vs. 'them', the construction of immigrants as animals, plants and commodities and as floods or invasions polarize immigrants from other people and portrays them as inferior human beings.

Using Critical Discourse Analysis (CDA), Makamani (2010) carried out an analysis of hate language in political discourse in Zimbabwe. He used as primary data, speeches made by president Mugabe and his allies while, secondary data was obtained from the media. He stated that the campaign messages that president Mugabe churned during the 2008 elections were so evasive and persuasive that one is tempted to take them at face value without questioning his commitment. Such an interrogation of Mugabe's commitment is vital for it enables one to appreciate the force behind language for deception. Even though the study did not look at the metaphors that could have been used by Mugabe and his officials during the 2008 election campaign, it exposed how inclusion (we/our) and exclusion (them/they) linguistic strategies associated with hate language could be used to divide a nation and thus precipitate violence along political party lines and even along tribal lines.

Michira (2014) applied critical and descriptive methods of CDA to study the football commentary metaphors used by two presidential contenders in Kenya during the 2013 general elections as a rhetoric strategy. The study concluded that various rhetorical and semiotic techniques communicated concealed messages. It further concluded that such coded communication techniques could have been used to avoid contravening the provisions of the Constitution and the attendant legal challenges. The speakers presented a "national" image rather than the real "ethnic" identity, thereby disguising harmful party ideologies.

With focus on metaphor and the Kenyan national political campaigns of 2005 and 2007, Orwenjo (2010) used a corpus analysis to calculate "metaphor power indices" (p.69) and demonstrated that the use of metaphor in political discourse serves as a device for manipulation of the electorates' emotions, intensifies during campaigns and crises and can bring about undesired non-linguistic consequences such as violence.

On the other hand, Vestermark (2007) used the Cognitive-Semantic approach originated by 
Lakoff and Johnson (1980) to analyze the conceptual metaphors 'THE WORLD AS A COMMUNITY, NATION AS A PERSON and NATION ACTING AS HUMAN.' Her method of analysis was to locate the conceptual metaphors mentioned and to analyze how a non-human entity (America) is specified as being a human entity and also to account for the probable intention of the speaker. She drew a conclusion that the four presidents used metaphors to personify the nation to make Americans to identify with and understand their beliefs and goals for America. Vestermark thus concluded that America was personified in the speeches to rally all Americans behind their country.

A study of the 'Yutong' bus metaphor in Ghanaian political speeches, carried out by Mensah (2012) using Lakoff and Johnson"s (1980) Conceptual Metaphor Theory (CMT), demonstrated that features of conceptual sources can be manipulated for positive rhetorical ends by politicians. He used the 'Yutong' bus metaphor to show that politicians in Ghana and elsewhere can employ metaphor to discuss serious political issues without resorting to insults of their political opponents. The study further demonstrated that negative associations which become a part of a conceptual source over time become naturally transferred unto features of the target domain. All these can be explored for the purpose of proper communication.

\section{Theoretical Underpinning}

Conceptual Metaphor Theory (CMT) and Critical Metaphor Analysis (CMA) are theoretical traditions that focus on metaphors as forms of organizing conceptual structure. While CMT is a prominent framework within Cognitive Linguistics, CMA is cross-fertilization between cognitive linguistic (CL) accounts of metaphor, and Critical Discourse Analysis (CDA). A combination of the two is appropriate for research on metaphors in political discourse since CMT enriches us with the theory of domains while CMA assists in specifying the role metaphors play in structuring our social reality (Charteris-Black 2004).

Conceptual Metaphor Theory views metaphor as a cognitive instrument. In cognitive linguistics, conceptual/cognitive metaphor refers to the understanding of one idea or conceptual domain in terms of another. A conceptual domain can be any coherent organization of human experience. The regularity with which different languages employ the same metaphors which often appear to be perceptually based has led to the hypothesis that the mapping between conceptual domains corresponds to a neural mapping in the brain (Feldman $\&$ Narayan, 2004).

CMT further views metaphors as matters of conceptualization. Conceptual metaphors have a correlation between two conceptual domains. Deignan (2005) states that conceptual metaphor theory views metaphor as a link between the source domain which is physically experienced and the target domain which is abstract. When we use metaphor, we map features from a source domain onto a target domain. The metaphor 'life is drama,' for instance, maps the properties of the source domain (drama) onto the target domain (life). With conceptual metaphors, the source and target are conceptual domains and are not based on similarities between entities. To Lakoff and Johnson (1980:246-247), "conceptual metaphor is a natural part of human thought and linguistic metaphor is a natural part of human language." 


\section{MInstitute Macrothin}

Lakoff and Johnson (1980) view metaphors as primarily matters of thought and action, only derivatively of language. To them, there is a close correlation between language, metaphors and thought and whether consciously or not, people think in metaphors. Lakoff, (1993:203) asserts that "The locus of metaphor is not in language at all, but in the way we conceptualize one mental domain in terms of another." Metaphor allows us to understand one domain of experience in terms of another. Thus, it is possible for us to make use of a relatively familiar, tangible domain of experience to deal with a relatively unfamiliar, less tangible domain of experience. For proponents of CMT therefore, thought has primacy over language.

Metaphor uses language to activate unconscious emotional associations and influences our values and beliefs by transferring positive or negative associations into the metaphor target (Charteris-Black, 2005). In the metaphor 'Man is a wolf,' used by Max Black (1962), the subsidiary subject ('wolf') calls to mind a 'system of associated commonplaces' which are generally accepted characteristics of wolves, whether they are actually true or not. It is in this regard that the associations made by metaphors used by politicians during the 2005 Draft Constitution referendum in Kenya would either be unifying or divisive.

The attempt to combine the CMA tradition with the CL tradition stresses the common ground between the two approaches: that language shapes our thoughts and practices. They structure our perceptions and understanding. So, the conventional metaphors in the discourses of religion, war, sport, business, politics and so on, tend to determine our consciousness and practice in these social spheres. The conceptual metaphor 'ARGUMENT IS WAR,' for instance, shapes our language in the way we view argument as war or as a battle to be won. We would think and perceive argument differently if the metaphor were 'ARGUMENT IS LOVE.'

Critical Metaphor Analysis' purpose, therefore, just like CDA, is to investigate and uncover ideology in so far as it is expressed and influenced by language and discourse. Stockwell (2000) quotes Fairclough's (1996) recognition of the importance of choice of one metaphor rather than another as a symptom of ideology. Ideology is either useful or harmful and this lends credence to the assessment of whether metaphors used by politicians in Kenya are unifying or divisive.

\section{Methodology}

\subsection{Sampling Procedure and Sample Size}

The study employed purposive sampling in which both metaphors by advocates for the "No" and the "Yes" campaign groups were collected. Purposive sampling enabled the researcher to use cases that had the required information with respect to the objective of the study. Cases of subjects were therefore chosen because they possessed the required characteristics. This view is consistent with that by Marshall (1996) and Rees (1997).The study's sample, therefore, consisted of a combination of metaphorical expressions of those who campaigned against and those who campaigned for the Draft Constitution. The study used a sample of sixty nine (69) instantiations of metaphor.

\subsection{Data Collection Procedures}

Data for the study was obtained from verbatim newspaper reports of the constitutional 
referendum campaign rhetoric used by the proponents of the two competing camps during the 2005 constitutional referendum in Kenya. The metaphors were obtained from two mainstream daily newspapers in Kenya-the (Daily) Nation and The Standard. To obtain the data, the researcher used the Metaphor Identification Procedure developed at Vrije University, Amsterdam (MIPVU) to identify metaphorically used items in the speeches made by the campaigners during the referendum.

To ensure the reliability of the coding, the researcher used four coders (two PhD Linguistics students and two secondary school teachers of English) who had been trained on the use of MIPVU. This is consistent with Riffle et al. (2005) who state that before carrying out the inter-coder reliability test, it is essential that the coders are properly trained in using the coding. The coders were therefore properly trained on how to use MIPVU to identify Metaphor Related Words (MRWs).

Each of the four coders, including the researcher, who worked independently, was given 120 newspaper leaves. They carried out document review to look for verbatim reports of politicians' speeches relating to the 2005 constitutional referendum campaigns. Each coder then determined the lexical units in the text identified. For each lexical unit in the text identified, the coder established meaning in context. Each coder then determined the basic meaning of the lexical unit by checking the first more concrete meaning of a lexical unit which was listed in the dictionary and adopted it as the word's basic sense. According to MIPVU, the first meaning in the dictionary is always considered the basic and concrete meaning of a word. Three dictionaries were used to define the word meanings: The Macmillan English Dictionary for Advanced Learners (Rundell and Fox, 2007), the Longman Dictionary of Contemporary English (Summers, 2005) and the Oxford English Dictionary (Simpson and Weiner, 1989). The Macmillan Dictionary for Advanced Learners (Rundell and Fox, 2007) was used to support the intuitions of the analysts in deciding on the metaphorically used textual elements since it is 'recent and corpus based' (Steen et.al. 2010).Each coder then decided whether the basic meaning of the lexical item was sufficiently distinct from the contextual meaning and whether the contextual meaning was related to the basic meaning by some form of similarity. If the last two conditions were met, the unit was marked as metaphorical, and hence the phrase or sentence. The reliability of coding was then assessed through an inter-coder reliability check. Where there was disagreement, the Longman Dictionary of Contemporary English was consulted. The Oxford English Dictionary was consulted where the aforementioned dictionaries were not useful. A group discussion was then carried out to resolve such cases of disagreement so as to reduce analyst bias.

\subsection{Reliability of Analysis}

The assessment of results from the inter-coder reliability tests consists of determining whether the score test is above or below accepted reliability standards. According to Krippendorff (2004), analysts can check the reliability of content by duplicating their research efforts under various conditions and check the similarities and differences in readings, interpretations, responses to, or use of given texts or data. Neuendorff (2002) concludes that coefficients of agreement of .90 or greater would be acceptable to all, .80 or greater would be acceptable in 
most situations and below that, there exists great disagreement. However, Cameron (2003) states that where the inter-coder reliability rate is $75 \%$ or more, the lexical unit is accepted as a metaphor. Cameron's rating was adopted by this study and each coder therefore represented $25 \%$. A total of 69 instantiations of metaphor of politics were therefore found with varying degrees of agreements of either $75 \%$ or $100 \%$. The instantiations obtained allowed an initial overview of the appropriate metaphorical concepts used to reflect upon politics in Kenya.

\subsection{Reconstruction of Metaphor Models}

From the metaphorical expressions identified, reconstruction of metaphor models was done. In reconstructing metaphors, all metaphors belonging to the same image source and describing the same subject area were grouped into metaphorical concepts. The process of allocating metaphorical idioms to metaphorical concepts was continued until all metaphorical manifestations were listed under concepts. The study notes that metaphorical idioms do not occur by chance, but as a rule can be traced back to a small number of common concepts. At the same time, they share the same source and target areas. The metaphors were therefore analyzed thematically by coding categories which were presented as different conceptual metaphor models. Six conceptual metaphor models were reconstructed from the instantiations using Systematic Metaphor Analysis (SMA) procedure. SMA (Schmitt, 2005), an approach to metaphor which attempts to reconstruct models of thought, language and action, draws on the results of Cognitive Linguistics by Lakoff and Johnson (1980), adding a step-by-step systematic reconstruction of metaphorical models. The metaphor models presented a rich data from discourses of politicians in Kenya and their conceptual mapping of issues.

\section{Discussion and Findings}

The study collected 69 metaphorical expressions form the political discourse of the campaigners. From the metaphorical expressions, six (6) metaphor models were reconstructed: 'POLITICS IS WAR; POLITICS IS RELIGION; POLITICS IS BUSINES/FINANCIAL TRANSACTIONS; POLITICS IS SPORTS/GAME; POLITICS IS NATURAL CALAMITY; and THE POLITICIAN IS AN ANIMAL \& HUNTER.' Discussed below are metaphorical expressions under the various metaphor models reconstructed.

\subsection{Politics is War}

The domain of war is employed metaphorically for all types of human struggle and conflict. War metaphors have, therefore, become an indispensable part of language (Ling, 2010).Foucault (1975) uses 'war' (or at least 'battle') as a 'model' for understanding social relations. In 'Society Must Be Defended' (1975-76), he conducts the genealogy of the war model. As a result of his investigation, the use of war in 'History of Sexuality' volume 1 (1976) is no longer epistemological, but practical; war is seen as a strategy for integrating a differential field of power relations. Naturally then, the 2005 Draft Constitution campaigners viewed politics as war. In this study, the 'POLITICS IS WAR' model had 23 metaphorical expressions.

In all the 23 metaphorical expressions of war collected, this study found the following words: beat (used two times), fight (used six times), battle (used three times), defeat (used two times), wrestle, quarrel, resist, invade, war, rebel, demons, show them, dagger, enemies, 
'mapambano' (battle) and revolt. These expressions paint a grim picture of the relationship of the different political camps and are actually war-like. Clausewitz (1976:88) remarks that 'the less intense the motives, war... will seem increasingly political in character' and by analogy, politics will seem increasingly military in character. The italicized words are military in character and structure our thoughts to view politics as war.

Six of the twenty-three metaphorical expressions '(a) (name withheld) has never beaten us here; (b) physically resist encroachment by the orange team into Nyandarua; (c) if they stop (name withheld) pension, then the (name withheld) and the (name withheld) communities will invade State House; (d) people should prepare for war if 'No' (the group opposing the draft constitution) wins; (e) (name of place withheld) should be at the forefront in the 'Yes' campaign and any rebel will be dealt with accordingly; (f) we have no time to flatter demons whose work it is to ruin the scheme of things' sum up the idea that war is employed metaphorically for human struggles and conflicts and equally is, as Clausewitz (1976:216) asserts, 'an act of mutual destruction.'

Metaphor (a) named a Kenyan political leader with a large following. The pronoun; us' was used with reference to a particular political grouping that was largely ethnic. The ethnic inclination is further realized when residents of a particular location are incited to stop the entry of political opponents into a particular area (metaphor b). This reflects political zoning of regions as political strongholds of particular ethnic communities, a common feature in Kenyan politics. Metaphor (c) mentioned senior political leaders whose ethnic communities were in a particular political camp during the 2005 constitutional referendum campaign. The government threatened to stop the pension of a retired president, who was viewed more as a member of a particular ethnic community other than as a senior citizen who had served the whole country. The ethnic inclination is sealed when those from particular regions, expected to support the position of 'one of their own' did not, and were, therefore, referred to as demons and rebels (metaphors (e) and (f). The metaphors support the idea that politics is indeed war (see metaphor (d)), albeit with a different kind of weapon. The contexts of use of all the metaphorical expressions of war in this study, therefore, bring forth a negative connotation. The metaphorical expressions, therefore, exhibited a negative axiological value, and hence, are divisive.

In conclusion, Kenyan politics is ethnic in nature (Michira, 2014).The ethnic-based Kenyan politics captures the 'POLITICS IS WAR' metaphors. The image of war in political campaign in Kenya is so deep that it causes divisions akin to what we see in an actual war situation. War is thus divisive, so is Kenyan politics, aided by the metaphors used by the political campaigners.

\subsection{Politics is Sport}

In 2000 Mandela said this about the power of sport:

"Sport has the power to change the world. It has the power to inspire. It has the power to unite people in a way that little else can. Sport can awaken hope where previously there was only despair.' (Nelson Mandela, Laureus Sports Awards Ceremony: 2000) 
Beacon (2000) stated:

Sport is the means by which continued cooperation and economic development of a special type is transmitted across the globe. Sport becomes a vehicle for diplomacy, ideology, nation building, access into the international arena and commercial gain.

Sport is used to promote nationalism. Nationalism is emphasized by international sporting events: "there is the articulation between sport and political nationalism. [..] Sport has become a significant international currency. [..] They are 'our boys/girls', and represent us in the international sphere...." [..] (Hargreaves, 1985:65). In this respect, sport has been used to reinforce nationalist attitudes.

Sport, however, can be used as a vehicle for harmful ideology. Sport history is full of examples where sport nationalism has perverted sport. The most infamous example of this is when Germany was hosting the Olympic Games in 1936; a scandalous arrangement where Hitler and the Nazi Party exploited the Games for their own ideological purposes. Not only regimes, political groups and individuals have been aware of the impact a big sport event can bring ever since. A notable example was the Black Panthers' action during the Olympic Games in Mexico City in 1968, where the American runners Tommie Smith and John Carlos gave a Black Power salute during the prize ceremony. This study found four (4) sport metaphors: (g) although I wrestled with president (name withheld) for the top seat, he called me into his government to neutralize and quash the plan to remove him from power; (h) ...but now the wrestling match is in the public court; (i) it is like asking the legendary athlete (name withheld) to run 1500 metres without a competitor and later declaring he had won the race; (j) I urge you all to maintain peace. We are in the Super League and we do not want any division, violence and chaos....

Metaphors (g) (h) and (i) portray politicians as engaged in physical combat (wrestling) and stiff competition (athletics), both of which are meant to outdo the opponent. Politics is thus viewed as a contest between a pair of wrestlers and athletes, each trying through physical force to make the other incapable of further resistance (Clausewitz 1976). Sports competitions have been, in this respect, seen symbolically as wars. Even though sport does not always lead to actual wars, sport has been used to reinforce nationalist attitudes and sentiments that have led to serious conflicts between opponents. This was the case between Honduras and Salvador in 1970 when nationalist sentiments led to a four day war. More than two thousand civilians were killed. Just as it may happen in sports, many Kenyan politicians whip ethnic attitudes and sentiments that create conflicts between their largely ethnic supporters.

However, metaphor (j) paints a different picture. It portrays the speaker as a team player and calls for peace to avert any chaos and violence. The 'Super League' is an advanced stage in sport and unity of the team is crucial at this stage. Even though the speaker addresses his supporters, this message cuts across the political divide and demonstrates that peace is vital in politics. The metaphor calls for unity and, therefore, has a positive axiological value. Even metaphor (g) portrays unity and inclusiveness. Even though there is 'war' during the wrestling match, (read 'competition during the political contest'), an olive branch is extended to the opponent. This is an indicator of inclusivity. However, this is done for selfish reasons: to quash 
the opponent's removal from power. The selfishness is further seen in metaphor (i) which emphasizes the selfishness of politicians, who make every attempt to ensure that they either have a weak or no competitor at all. From the foregoing discussion, it is evident that sport is viewed as war, both of which are meant to outdo the opponent. It is thus true that as we watch sports contests, we are actually watching war in a disguised form. Of the four sports metaphors collected, only one is outright unifying.

\subsection{Politics is Religion}

Religion is understood as a "system of beliefs and practices" by which a group of people interpret and respond to what they feel is sacred and supernatural (Molner, 1988). From a sociological point of view, religion is pragmatic in every society. It forms the basis, the core or the binding thread of all human activities. Religion profoundly affects societies and peoples' lifestyles (Iannaccone, 1998). Religion is, therefore, intertwined with the political, the social and the psychological life of communities. Jost et al. (2014) assert that

Religion provides anideological justification for the existing social order, so that

Prevailing institutions and arrangements are perceived as legitimate and just and

therefore worth obeying and preserving (Jost , Hawkins, Nosek, Gosling, Graham, Hennes, \& Stein, 2014).

In this study, fourteen (14) instantiations of the metaphor model 'POLITICS IS RELIGION' were identified. Since politics and governance are strongly related to patterns of inclusion and exclusion and on linguistic, ethnic and regional identity in Kenya, the ethnic perspective was found in the metaphorical expressions used during the Kenyan 2005 Draft Constitution referendum campaign:

(k) (name of region withheld) should be at the forefront in the 'Yes' campaign and anyrebel will be dealt with accordingly. We have no time to flatter demons whose work it is to ruin the scheme of things.

In the foregoing metaphor, people expected to belong to a particular political affiliation by virtue of their region of origin and community, but were not supporting the views of the leader from that region and community, were referred to as 'rebels' and 'demons.' They were viewed as interfering with the opportunity of that community to retain or gain power, and were, therefore, enemies just like the competitors who are exorcised in the following metaphor:

(1) There are two arch-enemies in Kenya today: (name withheld) and (name withheld).

(name withheld) 'ashindwe' (down with (name withheld)). (name withheld) 'ashindwe' (down with (name withheld))

The crowd was led in exorcising the two politicians the same way Christians exorcise the devil. The enemy deserves destruction at all costs, for without it, people of the region would follow the 'righteous' path. 
Reference to the proposed Constitution as the 'devil's advocate' in metaphor (m) 'the proposed Constitution is the devil's advocate; voting for it is to kill democracy' paints a black picture of the political opponent.The idea is that the proposed constitution would protect the 'devil'- the political opponent-who is not a democrat. The metaphor thus has a negative connotation.

Metaphor (n) '....the Wako draft for giving too much powers to the presidency making the office holder look like the Bible's King Pharaoh' reminds readers of the Biblical story of the Israelites who suffered in Egypt under King Pharaoh. A constitution that gives the presidency too much power would subject citizens to slavery the same way the Israelites were subjected to slavery in Egypt. This metaphor is, therefore, meant to urge the voter to reject the constitution which, according to the speaker, would lead to suffering. This metaphor elicits an unfavourable feeling among the voters and, therefore, has a negative axiological value.

On the other hand, the metaphor on the Biblical confrontation between David and Goliath compares the resources used by the two competing political camps, saying that the Orange (No) team had used less resources than the Banana (Yes) team to win the people's vote. The metaphor paints a negative picture of the opponent who is portrayed as a reject, having been rejected by voters despite the massive resources at their disposal. The comparison also reminds the electorate of the violent conflict that David and Goliath were involved in. It is meant to demean the giant opponent who could not measure up to the little David. The metaphor, therefore, exhibits a negative axiological value.

The metaphor 'This is just like the parable of the Prodigal Son in the Bible...' has both a positive and a negative axiological value. When the son asked for his share of the father's wealth and left home, the father experienced psychological conflict. The son too, experienced psychological torture when he had squandered his wealth and had to feed with the pigs. When, however, he returned home after squandering the wealth and he was given a warm welcome by the family, his spirit was raised. Equally, the father was relieved and elated. The homecoming demonstrates the understanding and the accommodative nature of the father. It was a positive move that demonstrates to the politicians that they need to accommodate their opponents after an electoral session so that a win-win situation can prevail. The metaphor is thus divisive in one sense, and unifying in another.

Of the fourteen metaphors of religion, six (6) portrayed a negative axiological value, one (1) was both positive and negative and the other seven (7) were non-committal. The study thus notes that even metaphors of religion, that would have been expected to propagate peace and inclusion, do not do so. The metaphor of David and Goliath, for instance, invokes war-like tendencies. Coupled with the ethnic tendencies in the metaphorical expressions of religion, the metaphors are divisive rather than unifying.

\subsection{Politics is Business/Financial Transactions}

Politicians seeking re-election have a strong incentive to manipulate fiscal policy to their benefit. For instance, there was an increase of more than 6 percent in public expenditure in the pre-election year in 17 Latin American countries between 1947 and 1982, (Ames, 1987). Bond spreads also increase during electoral periods (Reihnart, 2002; Reisen, 2002). Bond holders 
view elections as periods of uncertainty, and hence of increased risk. At the same time, during electoral periods, there are sudden swings in capital flows and also currency devaluation. Politics is thus not neutral in financial markets. As Santiso (2003) puts it, at the heart of financial transactions lies the question of confidence. Part of the confidence lies in the interaction between politics and economics.

The metaphor model 'POLITICS IS BUSINESS/FINANCIAL TRANSACTIONS' treats politics as a business. Business is, therefore, mapped onto politics while business people are mapped onto politicians whose aim is to 'buy' the goods (read the electorate). The study identified thirteen (13) metaphorical expressions used to conceptualize politics as a business during the 2005 constitutional referendum campaign in Kenya.

Most of the money matter issues during the 2005 constitutional referendum campaign period were construed as corruption. There was, for instance, increased government spending to win the voters. A campaigner observed that money was being used to woo voters and remarked:

(o)We are aware that money has been poured to woo voters.

There was also increase of salaries that were not budgeted for. One campaigner for the Orange group remarked:

(p) The government is going to shower you with money, intimidate you, use state machinery, cancel our rallies....increase your salaries ....

Metaphors (o) and (p) point to misuse of resources by the government. The words 'poured' and 'shower' used in relation to money, a scarce resource, is meant to awaken the voters to the idea that the tax they pay is being embezzled. The metaphors are thus meant to rally the voters against the speaker's opponent.

There were also direct alleged cases of vote buying and bribery during the referendum campaign. The following metaphorical expressions captured that mood:

(q)The information we have is that there is buying of voters cards in different parts of the country....

(r) Some of these MPs have suddenly become very rich and their sources of wealth are questionable.

(s) Some of these MPs have become 'wakoras' (rascals). They are out to enrich themselves at the expense of other people.

The metaphors cited above are clear cases of corruption, a cancer that bedevils not only Kenya, but many other countries in Africa and the world. Part of metaphor (s) above is a direct insult in Kiswahili: "wakoras" meaning rascals. The allegation of corruption is further illustrated by metaphor $(\mathrm{t})$ and $(\mathrm{u})$.

(t) You may have defeated us in parliament under streams of money but the wrestling match is now in the public court. We will win.

(u) State House has been turned into a market for human beings. We see many delegations 
visiting State House daily. They are being promised new districts, universities and other things. Some are being bribed with title deeds.

Parliament is a respected house and the competition in there should be a competition of ideas, not money. Kenyan parliament has often been accused of corruption among its members. Cases of corruption both in parliament and in State House are a strong indictment on the two important houses that are symbols of unity for the country. Poor management of resources is a recipe for chaos, which is a threat to the unity of a country.

Further corrupt practices were equated to human beings being 'bought'. This was emphasized by yet other campaigners.

(v) Having said everything that there was to say, both political and on the Constitution, if he turns back public perception will be that (he) has been bought.

The study notes that corruption is a cancer that threatens the fabric of society and threatens the unity of a nation. In Kenya, people accused of corruption normally seek refuge in their ethnic communities, claiming that their communities are being targeted. This has been a source of disquiet among certain communities, and has in certain instances, led to verbal attacks between leaders of such communities and the authorities.

The study also found that politicians take advantage of the citizens' economic circumstances to win their votes. A campaigner captured this idea when he stated:

(w) A 'No' vote would amount to restoring our dignity which had been wrongly thought that they could buy through relief food.

(x) We are not chicken to be hooked by a few grains of maize.

(y) Those selling the community will pay for it when the time comes.

Metaphors (w), (x) and (y) were used in relation to one community from a dry region that saw an increased supply of relief food during the referendum campaign. This was perceived as a vote buying strategy, a common phenomenon during electoral periods in Kenya. The demeaning nature of the expressions cannot go unnoticed: buying dignity through food, chicken... hooked by grains of maize and selling the community. The bitterness of that community is expressed through the metaphor below:

(z) We shall vote with a lot of bitterness because we are not cheap.

All these metaphors exhibit a negative connotation meant to alienate one group of people from the other.

The metaphors discussed under the conceptual model 'POLITICS IS BUSINESS/FINANCIAL TRANSACTIONS' are demeaning to the voters who are viewed as commodities for sale. This view creates social division between the political class and the electorate and even between the electorates themselves. The electorates perceived to have been 'bought' are viewed as corrupt and cheap. This has led to stigmatization of certain communities as unprincipled and cheap. Negative outbursts about the political camps enticed with money 
create conflicts among the electorates. In general, metaphors indicating corruption, selfishness and outright lack of respect for individuals and communities threaten the social fabric of society and are, therefore, divisive rather than unifying.

The conceptual metaphor model 'POLITICS IS BUSINESS/FINANCIAL/TRANSACTIONS' treats politics as a business. It is, however, a business with a unique set of goods-the electorate, who are viewed as animals being hunted hence the conceptual metaphor model 'POLITICS IS AN ANIMAL' and 'THE POLITICIAN IS A HUNTER.'

\subsection{Politics is an Animal and the Politician is a Hunter}

Animals have been used in human speech all over the world. The repeated occurrence of animals in human speech to convey a variety of feelings, thoughts, and fantasies is well known (Kellert, 1997). According to Lawrence (1993), the greatest fulfillment to the human need for metaphoric expressions is found through reference to the animal kingdom. He opines that 'No other realm of such vivid expression of symbolic concepts through use of animals is as widespread and as enduring' (Lawrence, 1993: 301). To Shepard (1978: 247) 'symbolic images of animals ... enable humans to objectify qualities and traits.' Animal metaphors, which are both cognitively and culturally motivated, have therefore, been used in languages (Martsa 2000; Li 2001; Kovecses (2003).The usage and understanding of an animal metaphor involves some perception of attitudes, experiences or dispositions of both the speaker and the addressee.

The metaphor model 'POLITICS IS AN ANIMAL AND THE POLITICIAN IS AN ANIMAL AND HUNTER' treats politics as an animal and the politician both as an animal and a hunter. The study identified seven (7) metaphorical expressions with creatures and animals such as monster, donkey, dog, mongrel and horse. Except for the horse which is a strong, intelligent and social animal associated with the high class in Kenya, the other animals used had a pejorative connotation. The distinctive characteristic features of a donkey, a monster, a dog and a mongrel do not paint a picture of aesthetics in Kenya except where a dog is used as a pet. In dry areas where donkeys are precious, they are only used as beasts of burden. The stupidity of the dog is brought out in the following expression:

(a)... is like a $d o g$ which drops its piece of meat thinking that its image in the water is another dog with a bigger piece.

This was a degrading domestic animal metaphor used to compare a politician's behaviour to that of a dog.

To emphasize the pejorative nature of the use of animals in the discourse, one campaigner outright referred to the competitor as a monster.

(bb) (name withheld)... the monster should be hit on the head and killed so as not to destabilize the ... government.

Further, the draft constitution was referred to as a 'monster'

(cc) Kenyans wanted a devolved government but what they ended up with is a political 
monster.

The term monster, which derives from Latin 'monstrum,' meaning an aberrant occurrence, usually connotes wrong or evil. A monster is, therefore, morally objectionable, physically or psychologically hideous. The term is applied figuratively to a person with similar characteristics. The two metaphors (bb) and (cc) are, therefore, degrading animal metaphors in which the creature has been used to degrade both the politician and the constitution in question. The two are considered immoral and evil by the two campaigners and, therefore, need to be decimated.

Close to the monster metaphor was the 'mongrel' metaphor.

(dd) What we are up against is the mongrel called the Kilifi Draft.

A mongrel is a mixed breed dog, a result of no intentional breeding. Just like Aliakbari and Faraji (2013), who established that a worthless person or a dirty person is associated with a dog in the Khezeli dialect, West of Iran, the 2005 Draft Constitution was considered a mongrel (worthless) by those who campaigned against it. Mongrel is equally a degrading animal metaphor.

The English regard the donkey as a stupid animal while the Khezeli dialect in Turkey associates the donkey with an obstinate person. The donkey, a hornless domestic animal, has been used as a beast of burden in Kenya to ferry water and goods, especially in dry areas with poor road network. However, it is still not regarded highly by most Kenyans. A campaigner used the donkey metaphor:

(ee) I tell (name withheld)) to bring those councilors who look like street children to Kapenguria and he will understand why donkeys have no horns.

The use of this animal in Kenyan political rhetoric is, therefore, derogatory. A listener is left wondering why donkeys have no horns.

The negative axiological value of the animal metaphors is summed up in the following metaphor:

(ff) Like good hunters, we should scatter ourselves in all directions to trap the animal.

Metaphor (ff) views the politician as a hunter and the electorate as the hunted animal. The relationship between the hunter and the hunted is normally parasitic, with the hunter benefitting while the hunted lose their lives. It is this real life scenario that is replicated in this metaphor, hence, its negative axiological value.

In conclusion, therefore, politics and politicians are closely associated with animals. Animal-based metaphorical expressions treat animals as people and people as animals. In other words, the attributes of human beings are mapped onto animals, and the attributes mapped onto the animals are mapped back to human beings. Both wild and domestic animal names are used as metaphors to describe politicians. All the animal metaphors in this study are used pejoratively. With all these pejorative references, the politicians do not preach unity and inclusiveness. 


\subsection{Politics is Natural Calamity}

Natural disasters do not occur in vacuum but in a political space. Though not driven by politics, they are not immune to politics (Cohen \& Werker, 2008). In the United States, for instance, political considerations explain about half of all federal disaster relief (Garrett \& Sobel, 2003). The conceptual metaphor model 'POLITICS IS NATURAL CALAMITY' treats politics as a natural phenomenon beyond human control and responsibility. Human beings frequently get in the way of natural hazards such as earth-quakes, tsunamis, volcanoes, hurricanes, tornadoes, floods, draughts and wildfires, making them human disasters. The study identified six (6) metaphorical expressions used to conceptualize politics as natural calamity during the 2005 Constitutional referendum campaign in Kenya.

Due to the awesome power of these natural calamities, political leaders have equated their power to these natural hazards. During the 2005 Draft Constitution referendum campaign in Kenya, expressions relating politics to such natural calamities were made and their enormous power referred to:

(gg) I said it is going to be a tsunami; the only way to avoid it is to go to higher grounds.

A warning was sounded to those 'on the way of the tsunami':

(hh) I warned them ('Yes' team) to move to higher grounds, but those who fail to heed my advice will be swept into the ocean by the strong waves.

The enormous power and destructive nature of the tsunami is so grave that those who do not heed the call to vacate (join the opponent) have themselves to blame as they are swept away:

(ii) We warned them that a political tsunami will come if they do not give people a good Constitution. It has now swept them.

The expression in (ii) was in reference to the resounding defeat the 'Banana' (those supporting the Draft Constitution) had received from their 'Orange' (those opposing the Draft) counterparts. Those who heeded the call and decamped before the tsunami were spared the wrath of the tsunami:

(ji) She is welcome to the home of Orange campaigners and she has taken a clever step of decamping before the political tsunami makes a sweep.

While it is true that natural calamities cause massive destruction to human kind, politicians 'revel' in their enormous power of destruction.. Uses of expressions such as in metaphors (gg-jj) warn the opponent that they either join the group or be destroyed. These expressions are threatening and are used to instill fear in the competitors. They suggest the violence that the opponent would witness if they failed to join them. The threats are continued using the following two metaphors:

(kk)You the people of (name withheld) will be placing a knife on your neck if you vote for this draft.

(11) Our wave is so strong and no turn coat or reject will be left standing in the path of the 
leadership of this county.

Negative terminologies and expressions such as 'placing a knife on your neck,' referring to competitors as 'reject,' 'turn-coat' used in (kk) and (1l) are clear indicators of an exclusive mind bent on causing disunity.

\section{Conclusion}

The study notes that metaphors of war and natural calamities and the threats used during the 2005 constitutional referendum campaign in Kenya were scary and threatening. Such terminologies as quarrel, fight, battle, tsunami, knife, physically resist, defeat, war and dagger among others paint a picture of a war situation. The metaphors are, therefore, divisive rather than unifying.

Religion is expected to preach peace, but metaphors of religion chosen by the speakers had elements of violence in them. For instance, the sling in the David and Goliath metaphor inflicted pain on Goliath. Equally, the story of rebellion of the Prodigal Son inflicted psychological violence on the father. The metaphors were, therefore, traumatizing and, therefore, had a negative axiological value.

The use of metaphorical expressions with such creatures and animals as monster, dog, donkey and mongrel have pejorative connotations. The 'hunter' has at his disposal political rhetoric which is used to lure the 'animal'. The electorate is enticed using a variety of things including money, relief food, increased salaries among other things during electioneering periods. The political opponents are equally animals which can be "bought" (read bribed) so as to shift their political affiliations. With all these pejorative references, the politicians do not preach unity and inclusiveness.

Of the 69 metaphorical expressions used in this study, only three (4.35\%) contained messages of unity and inclusiveness, eight (11.59\%) were non-committal while fifty-eight $(84.05 \%)$ expressed a negative axiological value. $84.05 \%$ of the metaphors, therefore, expressed exclusion and hence disunity. With all the negative axiological values expressed by metaphors in this study, the possibility of violence during campaigns and during elections and hence disunity cannot be downplayed. In Kenya, violence during elections has been the norm rather than the exception. Kenya experienced Post-Election Violence (PEV) in 2007 where more than 1300 people lost their lives and more than 6000 families were displaced.

\section{References}

Aliakbari, M., \& Faraji, E. (2013). Conceptualization of man's behavioral and physical characteristics as animal metaphors in the spoken discourse of Khezel people. Linguistik Online, 59, 2/13.

Ames, B. (1987). Political survival. Berkeley: University of California Press.

Roberts, W. R. (1954). Rhetoric (trans.) New York: Modern Library.

Beacon, A. (2000). Sport in international relations: a case for cross-disciplinary investigation. The Sports Historian, 20(2) 2000, 4. https://doi.org/10.1080/17460260009443366 
Black, M. (1962). Models and metaphor. Ithaca. New York: Cornell University Press.

Cameron, L., (2003). Metaphor in educational discourse. London: Continuum.

Charteris Black, J. (2004). Corpus approaches to critical metaphor analysis. Palgrave: Macmillan. https://doi.org/10.1057/9780230000612

Charteris Black, J. (2005). Politicians and rhetoric: the persuasive power of metaphor. New York: Palgrave Macmillan. https://doi.org/10.1057/9780230501706

Clausewitz, C. von (1976). On war (Ed. and trans.). M. Howard and P. Paret Princeton: Princeton University Press.

Cohen, C., \& Werker, E. (2008). The political economy of natural disasters. Working Paper, 2008 08-040. https://doi.org/10.2139/ssrn.1071748

Deignan, A. (2005). Metaphor and corpus Linguistics. Amsterdam: John Benjamins. https://doi.org/10.1075/celcr.6

Fairclough, N., (1996). A reply to Henry Widdowson's 'discourse analysis: a critical view. Language and Literature, 5(1) 49-56. https://doi.org/10.1177/096394709600500105

Foucault, M. (1978). (Histoire de la sexualité, tome 1: La volonté de savoir (Paris: Gallimard, 1976). Translated by Robert Hurley as The History of Sexuality, (1): An Introduction. New York: Random House.

Focault, M. (1975). Surveiller et punir. (Paris: Gallimard, 1975). Translated by Alan Sheridan as Discipline and punish (New York: Vintage, 1979).

Foucault, M. (2003). ("Il faut défendre la société." Edited by Mauro Bertani and Alessandro Fontana. (Paris: Gallimard / Seuil, 1997). Translated by David Macey as "Society must be defended." New York: Picador.

Feldman, J. A., \& Narayanan, S. (2004). Embodied meaning in a neural theory of language. Brain and Language, 89. https://doi.org/10.1016/S0093-934X(03)00355-9

Garrett, T. A., \& Russell S. (2003). The political economy of FEMA disaster payments. Economic Inquiry, 41(3), 496-509. https://doi.org/10.1093/ei/cbg023

Hargreaves, J. (1985). Sport, culture and ideology. London: Routledge \& Kegan Paul.

Iannaccone, L. R. (1998). Introduction to economics of religion. Journal of Economic Literature, 36(3), 1465-1495.

Isabel, O., \& Velasco D. (2001). Metaphor, metonymy and image schemas: An analysis of conceptual interaction patterns. Journal of English Studies, 3(3).

Jost, T. J., Hawkins, C. B., Nosek, A. B., Gosling, D. S., Graham, J., Hennes, P. E., \& Stein, C. (2014). Belief in a just God and a just society: a system justification perspective on religious ideology. New York: New York University. https://doi.org/10.1037/a0033220

Kellert, S. R. (1997). Kinship to mastery. Washington, D.C: Island Press. 
Kövecses, Z. (2003). Language, figurative thought, and cross-cultural comparison. Metaphor and Symbol, 18(4), 311-320. https://doi.org/10.1207/S15327868MS1804_6

Krippendorff, K. (2004). Content analysis: an introduction to its methodology. London: Sage.

Lakoff, G., \& Johnson M. (1980). Metaphors we live by. Chicago: University of Chicago Press.

Lakoff, G., \& Johnson M. (1980). The metaphorical structure of human conceptual system. Berkeley: University of California. https://doi.org/10.1207/s15516709cog0402_4

Lakoff, G., \& Turner, M. (1989). More cool reason, a field than guide to poetic metaphor. Chicago: University of Chicago Press. https://doi.org/10.7208/chicago/9780226470986.001.0001

Lakoff, G. (1993). 'The contemporary theory of metaphor.' In Ortony, A. (ed.), Metaphor and thought (2nd ed.). New York: Cambridge University Press .202-251. https://doi.org/10.1017/CBO9781139173865.013

Lawrence, E. (1993). The sacred bee, the filthy pig, and the bat out of hell. Animal symbolism as cognitive biophilia. In the Biophilia Hypothesis, 301 - 340 (Eds. S. Kellert \& E.O. Wilson) Washington D.C: Island Press.

Li, G. (2001). Figure of speech and glossary. Shanghai: Shanghai Foreign Language Education Press.

Makamani, R. (2010). An analysis of hate language in political discourse in Zimbabwe. In The Language of Politics in Africa. Cambridge: Cambridge Scholars.

Martsa, S. (2000). On animal frames in English and Hungarian. In: Mogensen, Jens/ Pedersen, Viggo/Zettersten, Arne (Eds.) (2000). Proceedings of the Ninth International Symposium on Lexicography at the University of Copenhagen. Tübingen, Niemeyer: 113-124.

Marshall, M. N. (1996). Sampling for qualitative research. Family Practice, 13(6), 522-525. https://doi.org/10.1093/fampra/13.6.522

Mensah, E. O. (2012). The Yutong bus: representations of a new Ghanaian political metaphor. Theory and Practice in Language Studies, 2(1). https://doi.org/10.4304/tpls.2.1.118-125

Michira, J. N. (2014). The language of politics: a CDA of the 2013 Kenyan presidential campaign Discourse. International Journal of Education and Research, 2(1).

Molner, T. (1988). Twin powers: politics and the sacred Michigan. Eerdmans.

Neuendorf, K. A. (2002). The content analysis guidebook. Thousand Oaks, CA: Sage.

Opeibi, T. (2006). Political marketing or political "macheting?" A study of negative campaigning in Nigerian political discourse. Retrieved from http://www.inst.at/trans/16Nr/01-4/opeibi16.htm

Orwenjo, D. (2010). Of shifting goal posts and scoring own goals: patterns of metaphorical 
language use in Kenyan political discourse. In D. O. Orwenjo \& J. O. Ogone (Eds.) Language and Politics in Africa: Contemporary issues and Critical perspectives (pp. 52-81) Cambridge: Cambridge Scholars.

Oxford English Dictionary (1989). Oxford: Clarendon Press.

Rundell, M., \& Fox, G. (2007). Macmillan English dictionary for advanced learners. London: Macmillan.

Rees, C. (1997). An Introduction to research for midwives. Cheshire: Books for midwives.

Reihnart, C. (2002). Default, currency crises and sovereign credit Ratings. NBER Working Paper, No. 8738, January Cambridge, M.A. NBER. https://doi.org/10.3386/w8738

Reisen, H. (2002). Ratings since the Asian crisis. Discussion paper, No. 2002/2, January. WIDER United Nations University.

Riffe, D., Lacy, S., \& Fico, F. (2005). Analyzing media messages. Using quantitative content analysis in research (2nd ed.). New Jersey: Mahwah, 138-155.

Rozina, G. (2001). The Use of language in political rhetoric: linguistic manipulation. SDU Fen Edebiyat Fakültesi Sosyal Bilimler Dergisi, Mayis 2009 Sayi 19 ss 120.

Sandikciouglu, E. (2000). More metaphorical warfare in the Gulf: Orientalist frames and news coverage. In A. Barcelona (Ed.), Metaphor and Metonymy at the Crossroads: A Cognitive Perspective. Berlin: Mouton de Gruyter.

Santa Ana, O. (1996). 'Like an animal I was treated': Anti-immigrant metaphor in US public discourse. Discourse and Society, 10, 191-224. https://doi.org/10.1177/0957926599010002004

Santiso, J. (2003). The political economy of emerging markets: actors, institutions and crisis in Latin America. New York: Palgrave. https://doi.org/10.1057/9781403973788

Schmitt, R. (2005). Systematic metaphor analysis as a method of qualitative research. University of Applied sciences Zittau/Goerlitz. Germany The Qualitative Report 10.

Shepard, P. (1978). Thinking animals. New York: Viking.

Steen, G., Dorst, A. G., Herrmann, J. B., Kaal, A. A., Krennmayr, T., \& Pasma, T. (2010). A method for linguistic metaphor identification: from MIP to MIPVU. Amsterdam: John Benjamins. https://doi.org/10.1075/celcr.14

Stockwell, P. (2000). Towards a critical cognitive Linguistics. In A. Combrink and I. Biermann (Eds), Discourse of war and conflict. Potchefstroom: Potchefstroom University Press, 1-21.

Summers, D. (Ed.). (2005). Longman dictionary of contemporary English (4th ed.). Harlow: Pearson Education.

Van Dijk, T. A. (Ed.) (1997). Discourse studies: A multidisciplinary introduction. London: 


\section{Macrothink}

International Journal of Learning and Development

ISSN 2164-4063 2019, Vol. 9, No. 2

Sage.

Vestermark, I. (2007). Metaphors in politics: A study of the metaphorical personification of American political discourse, an extended essay. Lulea University of Technology and Culture.

Wilson, J. (1990). Politically speaking. Basil: Blackwell.

\section{Copyright Disclaimer}

Copyright for this article is retained by the author(s), with first publication rights granted to the journal.

This is an open-access article distributed under the terms and conditions of the Creative Commons Attribution license (http://creativecommons.org/licenses/by/4.0/). 